\title{
Mind-blowing and desirable but challenging: Student perceptions of critical pedagogical teaching in university
}

FitzSimmons, Robert

University of Lapland, Finland

Suoranta, Juha

University of Tampere, Finland

Uusiautti, Satu $\bowtie$

University of Lapland, Finland (Satu.Uusiautti@ulapland.fi)

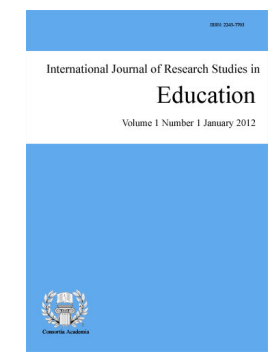

ISSN: 2243-7703 Online ISSN: 2243-7711

OPEN ACCESS

\section{Abstract}

Critical pedagogy is dedicated to having students deliberate in classroom praxis and to pose questions that may foster reflexivity when it comes to the ideological movement that is occurring. The purpose of this paper is to analyze the importance of critical pedagogy in higher learning institutions through two research questions: (1) What are university students perceptions of a critical pedagogy classroom and its usability in university studies? and (2) If given the opportunity, what would the students change about their university studies? Altogether, 124 university students' feedback was collected and analyzed with qualitative content analysis from five courses taught with the critical pedagogical approach at the University of Lapland, Finland. Their perceptions of critical pedagogy and desires for change in university teaching practices are introduced. Based on the findings, students had a strong desire for more teacher/peer contact and critical discussions in the learning process.

Keywords: critical pedagogy; student perception; higher education; reflexivity; neoliberalism 


\section{Mind-blowing and desirable but challenging: Student perceptions of critical pedagogical teaching in university}

\section{Introduction}

The first step in struggling against invisibility is to turn the world upside down, to think from the perspective of struggle, to take sides. (John Holloway, 2010, p. 157)

As higher educational workers, we have together well over 40 years classroom experience. This paper will be a reflection of that experience: not only do we attempt to relate our own experience in using critical pedagogy in the classroom but also in continuing the search for good learning practices. Our pedagogical ideas and aspirations are based on critical pedagogy, a social science tradition aiming to challenge oppression where oppression exists and create an equal society through dialogical educational praxis. Our focus is on giving students the tools necessary to be agents of inspiration and creativity throughout their adult lives, and more importantly, to be agents of social change. As such, critical pedagogy is a means of intervention into the daily affairs of life, as lived by people through tender acts of caring, for the species that inhabit the earth.

We believe that critical pedagogy has two main currents: movement and power. At this moment, the movement of our society is centered in neoliberalism, and power is in the hands of the one percent of the population and critical pedagogy sets its main task in challenging this movement and the neoliberal power impulse toward the marketization of the public and all that we hold dear: species life. (McLaren, 2003b, p. 171) Schumacher states, when commenting on our responsibility as educators: "Our responsibility for the future in higher education is openly to call into question the overall pattern of movement in our society, and in turn, the authority of power in our society" (Schumacher, 1991, p. 319). Critical pedagogy sets itself up as a pedagogy of resistance to the way such movement and power are now done in our society, especially when it comes to privatizing the public (McLaren, 2003b). Thus, schooling, which is an intrinsic part of the public terrain, is a marketplace where both power and politics are intertwined in 'lived cultures' (Keskitalo, Määttä, \& Uusiautti, 2013, p. 45).

Moreover, critical pedagogy is dedicated to having students deliberate in classroom praxis and to pose questions that may foster reflexivity when it comes to the ideological movement that is occurring. It is this current neoliberal movement and its power structure that we wish to not only confront but also to challenge, as practitioners of critical pedagogy in our higher learning institutions. We do not want our students to be 'passive consumers' of knowledge but rather active agents for social change. As such, we are concerned about the lack of a critical literacy in our society because when one ties together the personal and the political, dialogue and with it, the power to question becomes very important when confronting authorities of power and movement (Schumacher, 1991, pp. 318-319). What becomes important is for the student and educator to confront pedagogies of oppression, whether this is pedagogies of colonization of cultures or the colonization of the mind. For Keskitalo et al. this correlates into "the interplay between knowledge and learning" and "the experiences of the students and the teacher" (Keskitalo et al., 2013, p. 45).

We authors, as university teachers and professors, are part of a university system that has been under a neoliberal colonization of assault and structural reforms for several years. We are basically, regardless of our resistance to such colonization, part and parcel of the European power elite movement of revamping the education system toward neoliberalism (Rinne, 2000). These changes in the political and cultural context of higher education - the neoliberal model of globalization - have meant that research and teaching have been commodified through their dependence on market forces (Tabb, 2001). What we now have is a neoliberal version of education, which has had a tremendous impact in how and why knowledge is taught in the classroom and how 
such knowledge is used in everyday life. It now becomes crucial for educators and students not only "to theorize about and politicize the experiences" (Keskitalo et al., 2013, p. 45) of learning but also to actively confront 'pedagogic measures' that colonize the way we learn as a society.

Furthermore, the new neoliberal university, which has its roots in the transformations that occurred in the 1990's, lives on a constant diet of research projects which are funded from various sources outside the university. The end result is the compromising of knowledge because without project funding, there may be no work for the educator or the educator is classified as a loser who can only teach students----a symbol of the old university. On the other hand, the winning professor or lecturer in today's new reality can become a project manager who manages her own projects and those of her team and she can also apply for funds from various private institutions. Thus, the university has become a winner-loser semi-private enterprise with intense competition to generate one's worth within the cogs of the machine. At worst the situation is one of balance of horror, bellum omnium contra omnes, the war of all against all, in which those who are committed to their teaching are in danger to fail because they do not produce enough original research. And those who succeed in terms of a given standard, will build their own Research Fortresses, ranks and moral inside the university. What does this mean for educators who practice critical pedagogy and with it, a critical literacy? How can educators confront the acts of oppression that are experienced in small and large tangible ways in today's universities? And finally, what impact does this have on students?

\section{The neoliberal mantra and critical pedagogy}

The mantra often used by the Finnish educational elite is one of "efficiency, competitiveness, and individualism" (Määttä \& Uusiautti, 2014, p. 6) both in student life and in the life of the educational worker. According to the mantra, students can no longer regard the university as a critical space of learning. Nor can they regard their student life as a place for reflection. Rather, the university should, as the mantra goes, resemble a production line, a spectre of a new Fordism, a period of mass production of degrees, where the product, the student, must go through a quick assembly line procedure until the finished product is ready for work life. For the education worker, this correlates into upgrading their profiles, their own education brand, and the need to secure their jobs (Overberg \& Ala-Vähälä, 2018, 22). The key words are productivity and funding. The big question is according to the wording of neoliberals: what sort of product does the university produce? Sadly, the values of higher education have become a mirror of the corporate world, a commodified space, at the expense of a social ideology. Mary Worthen, writing in the International New York Times stated that for the corporate elite who populate university boardrooms and the political elite, who guide education policy, the importance of the 'cash nexus' is primary (Worthen, 2017).

For the educational worker, this may correlate into grants and research. The pressured worker who can get grant money through grant applications and the educational worker who can publish high quality articles and academic books are looked upon as being both productive and efficient. Accordingly, Overberg and Ala-Vähälä state that 'quality management' has introduced New Public Management (NPM) into university management practices, which has created more pressure and anxiety among the academic staff (Overberg \& Ala-Vahälä, 2018, p. 22). Overberg and Ala-Vahälä also claim that 'performance management' has brought a change in the ethos of being an academic. Thus, the quality of teaching has become secondary and being a cash generator for the university is primary. Neoliberal reforms have also impacted the workplace atmosphere as educational workers compete with each other for pay raises and bonuses. The pressure of publishing is real (see Uusiautti, 2015) as one example of the performance trends closely tied to university funding.

Tilly and Tilly (1997) have given us a definition of capitalism that seems to fit within the university structure. They state that capitalism is a "system of production in which holders of capital, backed by law and state power, make the crucial decisions concerning the character and allocation of work" (1997, p. 24). When it comes to higher learning this definition is important because of the neoliberal reforms that higher learning institutions have experienced. The collaboration of capital, transformations involving state power and reforms to 
the Finnish university law has had a tremendous impact on higher learning life quality.

Keeping in mind the neoliberal reform to Finnish higher education mentioned in this article, our purpose in this article is to search for the good practices and basic elements of good learning experiences and critical classroom practices in the context of critical pedagogy. We believe that critical pedagogy can be the key to the creation of good learning experiences because it ties itself to a genuine liberatory classroom praxis (see also FitzSimmons \& Uusiautti, 2013; FitzSimmons, Uusiautti, \& Suoranta, 2015). Furthermore, critical pedagogy places its foundation on giving the student a healthy dose of critical consciousness. In this we take Freire's definition of critical consciousness to heart: "learning to perceive social, political, and economic contradictions, and to take action against the oppressive elements of reality" (Freire, 1990, p. 15). It is this understanding of critical pedagogy that we want to embrace in our own classrooms.

By good learning practices, we refer to a teaching ethic that is oppositional and resistant to the way the ruling class is organizing its education systems and open to free thinking and awareness (e.g., Fallona, 2000; Uusiautti \& Määttä, 2012). In other words, good learning practices are oppositional toward the neoliberal state (see Moore, 2000, p. 152). Moore uses Shor and Freire (1987) to drive home his point. Students and educators need to demystify the ideology that is overseeing their education through discovery and recognition of the hidden curriculum and the power structures that are behind it. In other words, there needs to be more visibility in education practice (p. 152).

For example, Fallona (2000) calls for value clarification proposing that teachers use non-indoctrinating and nonjudgmental methods to help students discover and refine their values. Teachers may function as collaborators and guides with issues of fairness or morality being analyzed profoundly by paying attention also to care for one's self and others (Uusiautti \& Määttä, 2012). Fundamentally, teachers can create a critical learning environment that enhances students' development in higher-order thinking skills. Teachers should not only be able not only to clarify principles and educational goals but also to analyze them in a critical manner (e.g., Burns \& Rathbone, 2010), and, as Straughan (2000) adds, to develop students' autonomous self by helping them understand the wider picture by having them independently evaluate it.

However, it needs to be noted that critical pedagogy is a rather marginalized pedagogy within learning institutions. Perhaps this is due to the challenging nature of the pedagogy. By daring to challenge the neoliberal new world order critical pedagogy puts itself at odds with the Establishment who wish to see the university as an entrepreneurial institution or as a research enterprise on behalf of the corporate state (Moisio \& Suoranta, 2009). We believe that critical pedagogues who attempt to put the theory into practice face daunting challenges when they come up against a neoliberal education machine. By neoliberalism we refer to Verhaeghe who gave quite a relevant definition of how neoliberalism views humanity:

"People are competitive beings focused on their own profit. This benefits society as a whole because competition entails everyone doing their best to come out on top. As a result, we get better and cheaper products and more efficient services within a single market, unhampered by government intervention. This is ethically right because success or failure in that competition depends entirely on individual effort. So everyone is responsible for their own success or failure. Hence the importance of education, because we live in a rapidly evolving knowledge economy that requires highly trained individuals with flexible competencies. A single higher education qualification is good, two is better and lifelong learning is a must. Everyone must continue to grow because competition is fierce. That's what lies behind compulsion for performance interviews and constant evaluations, all steered by an invisible hand from central management" (Verhaeghe, 2014, pp. 112-113.)

Numerous thinkers have addressed this state of affairs for decades, among them Nobel laureate Albert Einstein (1979-1955) who as early as in 1949 claimed that "the economic anarchy of capitalist society as it exists today is, in my opinion, the real source of the evil" (paragraph 14) and has led "to crippling of the social 
consciousness of individuals" (paragraph 18). As he further argued, "[t]his crippling of individuals I consider the worst evil of capitalism. Our whole educational system suffers from this evil. An exaggerated competitive attitude is inculcated into the student, who is trained to worship acquisitive success as a preparation for his future career" (Paragraph 19.) The only durable cure according to Einstein would be to switch from capitalism to a planned economy "which adjusts production to the needs of the community, would distribute the work to be done among all those able to work and would guarantee a livelihood to every man, woman, and child" (paragraph 20). In this economic and social order, the education system would develop in the individual "a sense of responsibility for his (sic) fellow men in place of the glorification of power and success in our present society" (paragraph 20). Thus, in the present day university, where neoliberalism has become the dominant ideology, and where its hegemony has changed the basic understandings of why an university exists, the creation of a committed critical teaching practice can be much harder than before.

Furthermore, critical pedagogy takes not just commitment from the teacher but it also requires time and effort beyond the ordinary work of teaching. The pedagogy also requires various acts of concern from those educators who practice it in the classroom. We also need to remember that when it comes to neoliberalism, critical pedagogy is rather confrontational because it challenges the ideology from the standpoint of 'actual freedom' or thinking outside the box. The notion of actual freedom is very important for classroom practice because students need the courage to go outside the circle of 'formal freedom' and have the tools necessary to confront the neoliberal superstructure. This not only takes time from the teacher and student, it also takes a coordinated plan of attack.

The idea of actual freedom, where students and teachers have the skills necessary to confront and challenge the way things are decided, in a neoliberal society becomes very important for classroom practice and is very much a part of why we are writing this paper. We have seen immense changes in how universities function. From our own perspective, as educators who work within a Finnish university setting, we have seen a dramatic shift from a social democratic liberal university toward a more neoliberal model (Rinne, 2000).

This shift has had a tremendous impact on the current generation of university students and on those of us who have experienced the sea change in ideological directions. In this, we believe that personal experiences and histories in such settings become very important, and these personal experiences and personal histories should be shared from the position of 'actual freedom'. However, this will not be easy to accomplish because of the 'hidden curriculum' (Kivirauma, Rinne, \& Seppänen, 2003, p. 184) which seems to shape various learning situations in Finland. For McLaren this translates into: "teaching and learning styles ....messages that get transmitted to the student by the total physical and instructional environment, governance structures, teacher expectations, ....the tacit ways in which knowledge" is presented (McLaren, 2003a, p. 86).

\section{Method}

The purpose of this paper is to analyze the importance of critical pedagogy in higher learning institutions. In this, we refer to the ability of the student to engage in collective learning practices through deliberations, dialogues, and in the active questioning of the ideas and knowledge presented in their lectures and reading assignments. The central thesis of the paper is the importance of the teacher/student relationship in the higher education setting, through the emphasis that learning is a dual relationship between both parties.

Two main questions were set for this research:

$>\quad$ What are university students' perceptions of a critical pedagogy classroom and its usability in university studies?

$>\quad$ If given the opportunity, what would the students change about their university studies?

These questions will be answered by critically evaluating the feedback returned by students for five courses 
that students' attended during the spring term of 2018. This article is based on the research that was conducted in Dr. FitzSimmons' classroom, and therefore, this study resembles a qualitative teacher-as-researcher study (see e.g., Reis-Jorge, 2007). The goal was to create a classroom where creativity and reflectivity could take prime importance so that students could become the main actors for social change in their society, and not mere vassals for the recipients of knowledge. The students were given the course evaluations during the last day of the class, and returned to the lecturer before the last class ended. The evaluations were anonymous and the lecturer was not present when the evaluations were completed and put into a large envelope by the students. The feedback was completed by 124 students. The participants for the research were university first and second year students in Education and in the Social Sciences from the social science department and education department.

$>\quad$ The evaluations focused on 5 main parts: What was good about the course?; What was bad about the course?; What should have been more?; What should have been less?; and Other comments?

The evaluations were evaluated and analyzed by a qualitative content analysis (see Mayring, 2000) to see how the students reacted to courses where a critical pedagogical perspective was used in the classroom. The courses were given in the English language at the University of Lapland, which is located on the Arctic Circle in northern Finland. The course evaluations were analyzed and evaluated through a deductive and an inductive method.

$>\quad$ The main focus of this analysis was on two of these questions: What was good about the course? and Other comments? The students were very active in writing their thoughts and experiences about the courses and also about their learning experiences at the university so far.

The analysis of the data was performed by the research group consisting the authors of this article. The purpose was to ensure the reliability of the analyzing process through researcher triangulation (see also Wray, Marcovic, \& Manderson, 2007). Data itself appeared rich and students were willing to describe their thoughts and experiences widely and profoundly. The interpretations made in this research are complemented with data excerpts to show how students discussed the matters in the data. The data excerpts were anonymized to protect students' anonymity.

\title{
4. Results
}

\subsection{Student Perceptions of Critical Pedagogy}

The goal of the courses under investigation in this research was the use of a transformative language in the classroom, which would allow the students to break away from their imposed confinement in the classroom. Critical pedagogy in the classroom was considered to have the potential to put such a language into active use. This was perceived refreshing and exciting-even eye-opening. Students wrote in their evaluations of the course, for example, as follows:

\begin{abstract}
Discussions and debates. It was interesting to have a deeper look at the society where we are living in and also about the world and around us. It was interesting to get to know the different economical and political powers and ideologies which run this world. It was also great that we had students with different backgrounds and majors in our class. (Student No. 49)
\end{abstract}

Conversations and people participating pretty actively. Debates among students provided good exercise in the language learning context. (Student No. 101)

As previously stated, the work situation inside the universities is far from ideal. The market mentality that has co-opted the way learning is accomplished has eroded the quality of work and lessened the value of teaching in the classroom. Neoliberalism has created a situation where because of managerial decisions from the outside, educators must deal with constant changing administrative concerns that can work against the student's 
Mind-blowing and desirable but challenging: Student perceptions of critical pedagogical teaching in university

relationship with the educator and with their peers. All this does leave a critical educator with a problem but also (if given the opportunity) with a unique situation to practice critical pedagogy in the classroom and not just make it an exercise of theory to elaborate on in research articles.

For the critical educator, it becomes paramount that students are given alternatives to the dominant neoliberal discourse within universities and they are also given alternatives to the way knowledge is presented in the classroom. By presenting students with alternative discourses, it would allow the students to use their creativity and sociological imagination (Giddens, 2009) to be transformative agents of social change. Students seemed to learn new reflection skills through the critical pedagogical approach the teacher used as well as through conversations taking place in lessons. Apparently, students had not been given such opportunities to deliberate much. At least, the critical pedagogical approach of learning was widely thanked by the students in this data:

This course taught me to learn. That's really good thing given that some kind of effort has been conducted towards that over the past 12 years. Thank you. Not only on the behalf of myself but I feel that you've done a good deal for all of us as conversating and reflective students and citizens. (Student No. 103)

I liked to discuss the texts in small groups because there you get to hear other people's opinions and also ask their point of view if I didn't understand something in my text. It was also nice to discuss with the whole group. Discussion was good. (Student No. 106)

However, students did have problems when confronting the social issues. For example, in an oral skills class for social science students the main problem was the English language and a disengagement from their social reality. Many students found the topics difficult to discuss. This was surprising since most students had ten to twelve years English language study. The topics (as in the Education class) dealt with social policy issues that were being experienced in Finnish society and the reading assignments were basically taken from the Finnish news media's website: http://www.yle.fi/news. We found the comments from the students interesting because of their implications for Finnish higher education but also for their learning environments in Finnish high schools where fiscal discipline has been implemented in many Finnish municipalities. For example students stated:

New perspectives to issues that has happened and a lot of information (but) the topics to discuss were difficult. (Student No. 100)

Interesting and mind opening topics. Although topics were interesting, they were quite hard to talk about especially in English. (Student No. 77)

A lot of new topics and different points of view. Interesting. People seemed to be scared to tell their opinions. (Student No. 94)

One student gave a clue to what the problem was with some of the students and it also showed that students may be alienated from everyday social life. As one student stated:

Group talk was fun...I talked about things what I wouldn't talk normally. (Student No. 80)

Many students did make such comments and, therefore, the implication is that students may have difficulties discussing issues in their society even in the Finnish language. This may present a problem for critical pedagogues who are teaching in the university, if students have problems addressing social problems and their own moments of oppression in their native language. It is a signal that many students seem to be disconnected from the social commons.

\subsection{The students' desire for change in university teaching practices}

From the evaluations, a strong desire for more teacher/peer contact in the learning process was evident. 
Many students wanted to exchange knowledge with other students and have more contact classroom hours with the lecturer, professor and peers. The students would like to engage more with the course books on a social level by forming groups in classes, so that they can discuss the ideas that the authors are conveying in the printed word. Furthermore, there seemed to be a desire for a more critical university and a disdain for the current research university that they are now engaged in because of the innate desire to stake out a social claim through engagement with the wider society. They also wished for more new perspectives from their reading assignments in their subject class work so that new ideas can be shared with their peer groups and to engage in alternative discussions that will challenge the dominant discourse of neoliberalism.

As one student wrote:

I would like to have more discussion with small classes and more critical views. More group work and not so much essay writing/read book/go to test and get a grade. We need more contact teaching. (Student No. 4)

Other students also showed a desire for peer contact through group work in their learning situations when studying education or the social sciences. In fact, many students $(\mathrm{N}=9)$ seemed tired of lifeless lectures and the overwhelming of feeling alone in their study life. For example, several education students stated rather similar views about collaborative learning and their desire for change. These include: more group work and group discussions, more critical thinking, a desire for problem solving, more contact teaching, more social learning situations, and smaller class sizes.

What is clear from the above list is that students seem to have a beautiful spirit for learning to be human. They wanted human contact in the age digital technology and online courses and they have hope that more courses would focus on being more social oriented in learning situations. Students also seemed to have a desire for criticalness but because of the way the university is functioning in society and for what purpose it now functions in society, there seemed to be a disconnect from experiencing a critical engagement with their social reality. From the comments in the course evaluations, it could be interpreted that students were being prepared to be 'having beings' who live outside the world as mere objects in a commodified existence:

I really liked this course because it gives me a critical view not only about the Finnish system, but also about our society in general and how things actually work. (Student No. 25)

That we got to discuss ideas, to question things, and how the lecturer revealed the ideology and of ideas behind different things. That we learned to examine our environment closer and think more critically so that we don't take everything for granted. One of the best courses I ever had at the university. An eye-opening course. (Student No. 42)

The students appreciated that the course raised their critical consciousness as 'beings in the world'. In other words what the students seemed to desire is a 'reading of the world' and a connection to everyday life. And yet, this learning experience seems to be absent in many learning practices and situations in the university, if we go by the students' reflections and comments. It needs to be mentioned that the courses focused on using critical pedagogy in the classroom. For example, the oral skills course for education students took as its foundation an education for liberation, where students develop the skills necessary to free themselves from the various oppressions that they may experience in their lived social reality (Freire, 1985, p. 125). A sampling of student evaluations once the oral skills course ended were very positive about the direction of the course:

It was very informative, completely different from normal lectures in a good way. It was good to finally have conversations at university about topics that actually matter (this is how I imagined everything would be, how wrong I was. (Student No. 47)

The course provided us some good insight on some of the less desirable issues happening in our country that are not necessarily talked about as much as they should be. (Student No. 89) 
Mind-blowing and desirable but challenging: Student perceptions of critical pedagogical teaching in university

A lot of things that dared to think! (Student No. 71)

The subjects were interesting and I got new things to think about and also got inspired. (Student No. 87)

We can refer to Mills when he asked a simple and yet, a complex question: Why must they study the trivial subjects they do, rather than confront the insistent and significant problems of our time (Mills, 1962, p. 234). The above student comments seem to concur with Mills: students do want to deliberate about real issues and not just read books to pass exams. Mills' question has significance for today. His question is relevant because as educators we need also to see the under belly of our societies and what exactly has the ideology of neoliberalism or free market capitalism has had on our students' higher education experiences. Students want the university to be a place where they are made to think critically but not just about the ideas found in their textbooks or course books but also about real issues that their community may be experiencing. Furthermore, they also want their thinking to be focused on questioning. They desire a learning relationship between thinking and questioning.

The course made me think more and question things happening around us. (Student No. 80)

\section{Discussion}

In order for an oceanic transformation to occur, the students would need to take an active initiative in their own liberation from the status quo adaptability that they may experience in learning settings. The students need to become active in the transformation (through active engagement) to become part of the learning process. As such, the power of language is all encompassing. The educator and the student have the ability to radically empower their lifeworld through being active in daily discourse with their fellow human beings, between educator, students and their peers. Language needs a revolutionary body to perform the transformations that will be needed for our collective advancement as a human community of individuals. Critical pedagogy has the ability to create such a language where the educator and the student are not mere appendages to the life process in the classroom but rather they become the organic life force inside their own social commons. It becomes a language of people's ability to be social agents for transformation at the expense of the neoliberal lifeworld. An active critical pedagogy, when it is brought out of the printed word and into the classroom has a very important role to play in this process since it is the educator and the student who create the classroom that can be a transformative engagement with social reality.

Although the courses were in oral skills, where Finnish students receive the opportunity to use their English skills and in reading comprehension and not a subject class in their fields of study, the students found the opportunity to become connected with their society through reading and deliberation, opportunities that were 'mind opening' for the students. The use of critical pedagogy in the courses was possible because the courses focused on communication. Various issues that had meaning in the students social reality were deliberated and discussed by the students: poverty, marginalization, unemployment, neoliberalism, the Washington consensus, social democracy, the working poor, bread lines, and many other issues that are being experienced in Finnish society. The lecturer did give some background to the articles during the open discussion at the beginning of class but the students were encouraged to think, to feel, and to question the ideas in the articles and to reach their own conclusions through peer group work. They were free to deliberate without educator involvement because the main goal was for the students to see the value of peer involvement in the learning process and to work as a community to solve basic social problems that their society is experiencing. The spirit of the class was to embrace what Kahn states is a questioning learning environment that "would promote civic cooperation, democracy, and positive cultural values as well as fulfill human needs for communication, esteem and being politically free with one another" (Kahn, 2010, p. 99).

We believe that it is important for the students to understand and experience the concept of conscientization---the dynamic and dialectical relationship not just between theory and practice (praxis) but also between reflectivity and action (Mezirow et al., 1990). By bringing aspects of lived reality into the learning 
situation, where real issues were deliberated and acted upon, the goal was to foster a critical resistance so that students can uncork their past experiences and become an action-oriented classroom community of critical and reflective human beings (see also FitzSimmons, Uusiautti, \& Suoranta, 2015). Foremost, our responsibility (as educators) was to seek an understanding with the students that we are teaching and to listen and to learn from the class as they related their opinions and viewpoints of the ideas that were brought up in the classroom deliberations. Finally, we wanted our students to feel empowered to resist when confronted with the small little moments of oppression that we may all experience in our lived neoliberal reality.

Students have a strong inclination to critically engage their social reality in learning situations. They also desire to have deliberations with their peers, a 'willingness to connect' with others in a social relationship in the classroom. Mills' "politics of truth” (Mills, 1962, pp. 234-235) becomes important, especially if students will garner the skills needed to confront oppression that they will find in their human condition through a process of engagement with their lifeworld. Critical pedagogy in the classroom can change the dynamic of learning by changing the use of language between educator and student in learning situations.

One aspect brought up by students was to increase social connection in the university education. They seemed to be genuinely happy about the learning environment provided in these particular courses that were analyzed in this research and to criticize the increasing number of online courses and self-study packages in higher education. Although online teaching is to provide equal opportunities to students participate in lessons, it seemed that these learning environments do have some shortcomings when it comes to critical conversation and social interaction. Since online teaching is and will be widely used in universities, we want to highlight the importance of teachers' abilities to create such online learning environments that would self-evidently include these elements of critical pedagogy. This will necessitate more from the teachers but it is not impossible (see e.g., Uusiautti, Määttä, \& Leskisenoja, 2017).

\section{Conclusion}

Peter McLaren of Chapman University states that "A critical pedagogy is about the hard work of building community alliances, of challenging school policy, of providing teachers with alternatives and oppositional teaching materials" (McLaren, 2016, p. 32). We would also claim that critical pedagogy can help students to use Freire's concept of 'conscientization' by given them the opportunity to see the contradictions in their society through observation and reflection (Freire, 1985, p. 124). Accordingly, McLaren claims that academics in the field of critical pedagogy "should 'make a commitment' to a specific action or consider as an 'obligation' their actions regarding the relationship between a specific premise and their concluding interpretations and explanations." This depends upon the idea that "interpretation and transformation and of the world are inseparable, that is, they "are linked socially and ethically." Committed academics embrace the idea of "a dialectical and critical self-consciousness of the relationship between being and doing (or being and becoming)," which is "an ethical rather than an epistemological" stance--ethnics always precedes epistemology in the field of critical pedagogy." As he concludes, "only ethics of compassion, commitment, and respect can guide us out of the neoliberal impasse that we face" (McLaren, 2016, p. 11.).

Indeed compassion, commitment, and respect are moral values, too, that can be fostered through critical pedagogy. For example, Berkowitz and Grych (1998) introduce eight aspects of moral functioning that should be paid attention to teaching. These are four meta-moral characteristics (social orientation, self-control, compliance, and self-esteem) and four components of psychological morality (empathy, conscience, moral reasoning, and altruism). According to their ideas, if stake-holders have equal power to enter and participate in democratic decision making and discussion, it is possible to enhance compliance, moral-reasoning development, conscience, self-esteem, and altruism (Berkowitz \& Grych, 1998).

Compassion, commitment, and respect are directly related to an empathic educational policy where educational workers and students can further investigate their own humanity or as Mclaren states, we a 
"revolutionary movement" where "compassion" and "social "justice" can flourish (McLaren, 2003b, p. 170). Without a commitment to enhance the empathic impulse, an interpretation of what is occurring in the education and social arena would be very difficult, likewise for a radical transformation of the world. Giddens puts emphasis on the sociological imagination and the ability to have human beings to see into the lives of others by putting themselves in their shoes (Giddens, 2009, p. 6; Krznaric, 2004, p. x). This could help create the social and ethical link needed for the empathetic impulse to prosper in the community and to help students and learners see just what neoliberalism does to the social commons and to the people who live inside it. Furthermore, this could be a way to unleash the compassion and respect needed to express and to show solidarity to the victims of neoliberalism and its ideology and to create a society of equals.

But what does a liminal classroom mean? "We can create a liminal classroom where all identities are levelled and we confront each other in an existential void as equals, or we can create the necessary distance for critical self-reflexivity, or we can engage in a dialectical dance involving both" (McLaren, 2016, p. 32). One very important way to establish a liminal classroom, where people are respected and the playing field is equal, is through educational settings that are collaborative and deliberative in content through face to face contact with peers, so that students upon graduation will participate in creating a good and active society. Etzioni put it into perspective when he wrote that an active society would put forward important values for discussion and such a society would garner as much political involvement of the citizenry as possible to democratize civil life (Etzioni, 1977, p. 47). He also stated that such democratization would put focus on more social justice (p. 47). This certainly can give a foundation for a liminal classroom when students and educators are involved in a critical pedagogical practice of sharing knowledge. Although lectures do have their place in the university, it also must be recognized that lectures, especially with large attendances, can offer a rather dearth knowledge base (Weller, 2011; see Kop, Fournier, \& Sui Fai Mak, 2011, p. 74) because of the lack of interchange of ideas.

That being said, Weller (2011) puts some stress on 'connectivism' and we believe that if put into the right context, it may offer some guidance for critical pedagogy in the classroom, especially when it comes to a liminal classroom. For Weller some aspects of connectivism are: learning through a differing of opinions, the ability to learn more than what is now known, the ability to nurture and keep connections open throughout a human being's learning process, and to keep connectivity with others, regardless of our workplace or studies.

All of the above can fit nicely into a critical pedagogy classroom. For us, the art of connectivism is rooted in connecting the human being into a 'pedagogy for human beings' and not for human 'havings' (see Fromm, 1976). We can celebrate our sameness and also our diversity through an interconnected understanding that we can differ and yet celebrate our humanity.

\section{References}

Burns, D. S., \& Rathbone, N. (2010). The relationship of narrative, virtue education and an ethic of care in teaching practice. In Education, 16(2). Retrieved from https://ineducation.ca/article/relationship-narrative-virtue-education-and-ethic-care-teaching-practice

Einstein, A. (1949/2009). Why socialism? Monthly Review. Retrieved from https://monthlyreview.org/2009/05/01/why-socialism

Etzioni, A. (1977). On changing societies. Current Sociology, 23(1), 39-47. https://doi.org/10.1177/001139217502300102

Fallona, C. (2000). Manner in teaching: A study in observing and interpreting teachers' moral virtues. Teaching and Teacher Education, 16, 681-695. https://doi.org/10.1016/S0742-051X(00)00019-6

FitzSimmons, R., \& Uusiautti, S. (2013). Critical revolutionary pedagogy spiced by pedagogical love. Journal for Critical Education Policy Studies, 11(3), 230-243.

FitzSimmons, R., Uusiautti, S., \& Suoranta, J. (2015). An action-oriented critical pedagogical theory. In S. Uusiautti \& K. Määttä (Eds.), Critical eye on education (pp. 9-28). Tallinn: United Press Global.

Freire, P. (1990). Pedagogy of the oppressed. London: Penguin Books. 
FitzSimmons, R., Suoranta, J., \& Uusiautti, S.

Freire. P. (1985). The politics of education. Granby, MA: Bergin and Garvey Publishers. https://doi.org/10.1007/978-1-349-17771-4

Fromm, E. (1976). To have or to be. New York, NY: Harper and Row.

Giddens, A. (2009). Sociology. Cambridge: Polity Press.

Holloway, J. (2010). Change the world without taking power. New York, NY: Pluto Press.

Kahn, R. (2010). Critical pedagogy, ecoliteracy, and planetary crisis. New York, NY: Peter Lang.

Keskitalo, P., Määttä, K., \& Uusiautti, S. (2013). Sami education. Frankfurt am Main: Peter Lang. https://doi.org/10.3726/978-3-653-01975-9

Kivirauma, J., Rinne, R., \& Seppänen, P. (2003). Neo-liberal education policy approaching the Finnish shoreline? The Journal of Critical Education Policy Studies, 1(1), 171-193.

Kop, R, Fournier, H., \& Sui Fai Mak, J. (2011). A pedagogy of abundance or a pedagogy to support human beings? Participation support on massive open online courses. The International Review of Research in Open and Distance Learning, 12(7), 74-93. https://doi.org/10.19173/irrodl.v12i7.1041

Krznaric, R. (2014). A handbook for revolution: Empathy. London: Random House.

Määttä, K., \& Uusiautti, S. (2014). Introduction. In K. Määttä \& S. Uusiautti (Eds.), Early childhood education in Finland (pp. 1-6). Abingdon: Routledge.

Mayring, P. (2000) Qualitative content analysis. Forum: Qualitative Social Research, 1(2). Retrieved from http://www.qualitativeresearch.net/fqs/fqs-e/2-inhalt-e.htm

McLaren, P. (2003a). Critical pedagogy: a look at the major concepts. In A. Darder, M. Baltodano, \& R. D. Torres (Eds.), The critical pedagogy reader (pp. 69-96). London: RoutledgeFarmer.

McLaren, P. (2003b). Revolutionary pedagogy in post-revolutionary times: rethinking the political economy of critical education. In A. Darder, M. Baltodano, \& R. D. Torres (Eds.), The critical pedagogy reader (pp. 151-184). London: RoutledgeFarmer.

McLaren, P. (2016). Pedagogy of insurrection. New York, NY: Peter Lang.

Mezirow, J., \& associates. (1990). Fostering critical reflection in adulthood: a guide to transformative and emancipatory learning. San Francisco, CA: Jossey-Bass Publishers.

Mills, C. W. (1962). Power, politics, and people: The collected essays of C. Wright Mills. New York, NY: Ballentine Books.

Moisio, O.-P., \& Suoranta, J. (Eds.) (2009). Kriittisen pedagogiikan kysymyksiä [Questions of critical pedagogy]. Tampere: University of Tampere.

Moore, A. (2000). Teaching and learning: pedagogy, curriculum, and culture. London: RoutledgeFalmer.

Overberg, J., \& Ala-Vähälä, T. (2018). Do the attitudes towards external quality management change over time? Journal of the European Higher Education Area, 2.

Reis-Jorge, J. (2007). Teachers' conceptions of teacher-research and self-perceptions as enquiring practitioners: A longitudinal case study. Teaching and Teacher Education, 23(4), 402-417. https://doi.org/10.1016/j.tate.2006.12.007

Rinne, R. (2000). The globalization of education: Finnish education on the doorstep of the new EU millennium. Educational Review, 52, 131-142. https://doi.org/10.1080/713664043

Schumacher, J. (1991). Our responsibility for the future in higher education. The Raven, 4(4), 305-323.

Shor, I., \& Freire, P. (1987). A pedagogy of liberation. New York, NY: Bergin and Garvey.

Straughan, R. (2000). Can we teach children to be good? Basic issues in moral, personal, and social education. Philadelphia, PA: Open University Press.

Tabb, W. (2001). Globalization and education as a commodity. Retrieved from http://www.psc-cuny.org/jcglobalization.htm

Tilly, C., \& Tilly, C. (1997). Work under capitalism: New perspectives in sociology. Boulder, CO: Westview Press.

Uusiautti, S. (2015). The pressure of academic publishing. In S. Uusiautti \& K. Määttä (Eds.), Critical eye on education (pp. 79-96). Tallinn: United Press Global.

Uusiautti, S., \& Määttä, K. (2012). Can teachers teach children how to be moral? British Journal of Education, Society \& Behavioural Science, 2(3), 260-270. 
Mind-blowing and desirable but challenging: Student perceptions of critical pedagogical teaching in university

Uusiautti, S., Määttä, K., \& Leskisenoja, E. (2017). Succeeding alone and together - university students' perceptions of caring online teaching. Journal of Studies in Education, 7(2), 48-66.

https://doi.org/10.5296/jse.v7i2.11162

Verhaehe, P. (2014) What about me? The struggle for identity in a market-based society. London: Scribe.

Weller (2011) A pedagogy of abundance. Spanish Journal of Pedagogy, 249, 223-236.

Worthen, M. (2017, May 17). On campus, manners and titles ensure respect. International New York Times.

Wray, N., Markovic, M., \& Manderson, L. (2007). "Researcher saturation": The impact of data triangulation and intensive-research practices on the researcher and qualitative research process. Qualitative Health Research, 17(10), 1392-1402. https://doi.org/10.1177/1049732307308308 
FitzSimmons, R., Suoranta, J., \& Uusiautti, S. 